\title{
From I Vecchi E I Giovani to Pirandellian Correspondence: A Glance at an Italy That Is Immutable in Both Its National and Its Family History ${ }^{*}$
}

\author{
Lucilla Bonavita \\ “Tor Vergata” University of Rome, Rome, Italy
}

\begin{abstract}
The novel I vecchi e i giovani has been the object of numerous critical interpretations, including those of Leonardo Sciascia, Gaetano Trombatore, and Massimo Onofri, in particular. Taking as its starting point Pirandello’s phrase, "la gioventù sacrificata potrebbe dare un crollo a questa oltracotante oppressione dei vecchi e prendersi finalmente uno sfogo e affermarsi vittoriosa" and applying Freudian principles, this work seeks primarily to highlight the autobiographical element that is expressed in the father/son, Luigi/Stefano, and Lando Laurentano/Stefano Landi relationships.
\end{abstract}

Keywords: old/young, father/son, Lando Laurentano/Stefano Landi, Freud

When it comes to national identity then, as Alberto Asor Rosa argues, literature undoubtedly wins first prize as mode of expressing a people. This is truer in Italy's case than in that of other European nations: The fact of having emerged late and laboriously has highlighted the identity-related value of all forms of expression and of literature, first and foremost. The dialectical process leading to the arduous realization of Italy's social and political identity finds its parallel, to speak only of the Risorgimento literature, in Foscolo, Manzoni, and Leopardi and its epilogue in Verga, De Roberto, and Pirandello. This short essay proposes to take a closer look at that dimension of Pirandello's fathomless galaxy that reveals the extent to which Italian literature echoes supranational human and literary values and offers irrefutable evidence of dynamics in which literary production and personal history (in this case, primarily the matters marking his troubled relationship with his son, Stefano) influence one another to the point of creating a unique literary fabric.

In Giovanni Macchia's opinion, Pirandello's work is a constantly open site: something labyrinthine, permeated, invasive, and pervasive. Marking the boundaries of his individual texts according to the formal discipline of literary genres is therefore a fruitless task. The element they have in common, on the other hand, could be identified as the dynamism circulating in pages brimming with a both constructive and destructive energy that, as Michail Bachtin maintains, gives voice to a dramatic polyphony: This is the vocation of this particular writer.

The Pirandellian phenomenon has its roots in a Sicily close to national unification. Unlike Verga and Capuana (who are founding fathers) and like De Roberto, Pirandello has behind him a generation of models who had risen to fame and were worthy of admiration. But whilst De Roberto grew up in Catania, run through

Lucilla Bonavita, Italian Studies Ph.D., “Tor Vergata” University of Rome, Rome, Italy. 
with Enlightenment thinking, Pirandello grew up in Girgenti, the back end of beyond and place of the Arche: Time stands still, frozen, and the glory of the place is impressive but now declining. Pirandello appears on the literary scene when the first convulsions of modernism seem to be setting a trap for the last outposts of eternity.

In accordance with a model by then de-codified and normalized by his predecessors, Pirandello, too, had to play the difficult role of the emigrant, living as he did in a geographical context that, whatever the journey undertaken, always becomes the concrete reality of emigration. Unlike his predecessors and his fellow students from the region, Pirandello graduated on German soil in Romance philology, with a thesis on the Girgenti dialect. At this point, the young Pirandello could have become one of the eclectic Sicilian intellectuals. Instead, aged only 26 and carried away by Capuana, he had a try at the genre of the novel. He began with L'esclusa, the fruit of a robustly energetic talent that picked up the legacy left by verismo and, at the same time, sought original new creative spaces: tracing a parabola that was to peak with the codification of a meta-narrative conception of modern Italian literature. When compared to both the mimetic model and the 19-century fantasy genre, the principal poetic function of the meta-narrative framework is to provoke.

In his essay entitled Spiritismo?, Capuana (1884) reworks the artistic creation motif, putting it at the service of a dissenting meta-discourse aimed at parodying the positivistic model. He makes no attempt to unveil the mystery of artistic inspiration and entrusts it to the scientists. Pirandello, too, seems to align himself with this position when he compares the mystery of artistic creation to that of "nascita naturale" (1972, p. 558), but, equally, he dedicates numerous pages to the subject both in essays and in his novellas.

Reproducing the central thesis of Binet's theory of the human psyche as a grouping of different elements, of various sub-personalities, Pirandello pinpoints the personality of the artist in his essay entitled Scienza $e$ critica estetica (Corsinovi, 1979, p. 61). Because normal consciousness "disgrega in tumulto", the artist "compone, costruisce, crea così dagli elementi del suo proprio spirito altri personaggi, altri individui in sé" (Corsinovi, 1979, p. 61) ${ }^{1}$. The fact that the "mistero dell'atto creativo" assumed a meta-literary form in both Pirandello and Capuana—naturalism's rebel sons—during the post-positivistic era in the late 19th and early 20th centuries, when interest in the phenomena of literary creation was being taken in the context of the new theories on the human psyche and conjugated according to the various paradigms emerging from the interdisciplinary philosophical-psychological-aesthetic system, is indicative. In parallel with Capuana, who abandons the concept of literature as depiction and substitutes it with that of reality's invention, Pirandello, too, in Tragedia di un personaggio, asserts a different reality and the autonomy of art; to such an extent that he attributes to it a truth that is higher than life. The most fruitful critical perspective for the purposes of this essay therefore appears to be the one inclining towards late 19th-century psychology and Alfred Binet's polypsychic theory of the personality (Ellenberger, 1999) ${ }^{2}$, founded on a rejection of the concept of "Ego" as a unique, permanent subject.

That heavily realistic 19th-century structure that had been firmly repressed in the name of a psychological and anthropological interiority in Pirandello's preceding novels nevertheless emerges in I vecchi e i giovani, thanks to the adoption of an omniscient narrator and the choice of the historical novel, following in the footsteps of De Roberto's I Vicerè and the masters of the genre. Published in volume form for the first time in

\footnotetext{
${ }^{1}$ The essay from which the quote is taken dates to 1900 and therefore belongs to the same period as that in which Capuana's collection appeared.

2 Binet's theory established the plural model of personality, according to which the subject's unity was no more than an illusion: Human personality appears to be a groupement of various elements.
} 
1913, I vecchi e i giovani was intended to be Pirandello's epic novel: the vicissitudes of the Laurentano family in the 1890s - during the period that saw the creation of the Sicilian Workers' Leagues and the class struggles between the clericalists and those supporting the new liberal regime-lie at the heart of the narrative. The generational conflict between the fathers who achieved Italy's Unification and the sons who sense the defence of obsolete rights in the formers' rigid conservatism, the appearance of the new capitalistic bourgeoisie, and the engulfing of the spirit of renewal that drove the Risorgimento are the fundamental elements of the cultural historical context emerging at the dawn of the new century. In such context, Mauro Mortara is an obstinate Garibaldian who is disillusioned by the epilogue to the Risorgimento's battles, don Flavio Salvo is a powerful banker who takes advantage of Italian society's decay, don Ippolito is a champion of the reactionary aristocracy remaining faithful to the Bourbons and his son, Gerlando, is driven by revolutionary ideas that are diametrically opposed to his father's traditionalism: The extensive documentary value of the novel, a first-class testimony on a crucial period of Italian national history, is quite evident. I vecchi e i giovani is an epochal fresco, a genre that does not belong specifically to Pirandello but which he tries his hand at in order to demonstrate something more or, perhaps, to free himself of it. In short, the novel constitutes the story of the Risorgimento utopia's failure, told by way of a mirroring game that, according to Sergio Campailla, sends one back to man's universality (Pirandello, 2012).

The critics have emphasized the presence of the geographical topos of Girgenti in the novel. Leonardo Sciascia has described the novel as Pirandello's most autobiographical work and, without emphasizing the father/son relationship, has taken a Freudian look at the absence of a father from the story (Sciascia, 1996). Gaetano Trombatore has amply highlighted the role that resistance plays (Trombatore, 1962, pp. 44-45) and Massimo Onofri has caught the profane motivations of characters who seem to be moved by personal interests (Pirandello, 1993).

Taking as my starting point Pirandello’s phrase, "la gioventù sacrificata potrebbe dare un crollo a questa oltracotante oppressione dei vecchi e prendersi finalmente uno sfogo e affermarsi vittoriosa”, I will seek to bring out the autobiographical element that runs like a karst river through the work, finding its expression in the father/son, Luigi/Stefano relationship. One almost seems to discern in it an evocative suggestion: an invitation from Luigi Pirandello to his son, Stefano, to free himself of the filial condition that so weighed on him that he lyrically referred to himself as "un figlio, sempre figlio..." and "figlio da sempre, io" (Pirandello, 2004) Stefano performed the various and complementary roles of secretary, agent, manager and aide to his father, controlling the dizzying system of personal and epistolary relations with journalists, critics, translators, actors, impresarios, lawyers, and editors with which Luigi's life was studded.

The novel that Pirandello considered his greatest labour by virtue of its dimensions, the vastness of its vision and its complexity as an organism teeming with figures, events and varied and conflicting passions, the novel in which he depicts all the moral collapse during the years following the enthusiasm of the Italian Risorgimento-a novel full of pain —is identified by that same Stefano as the place in which "Pirandello non faceva il vate, questa parte la lasciava al Carducci e al d’Annunzio”. However, as Stefano goes on to state, “[...] negli incisi, specie nei Vecchi e i giovani, ma anche in tanti e tanti altri luoghi, i suoi sentimenti politici trovano espressione” (Pirandello \& Pirandello, 2008, pp. 98-99). The intellectual collaboration between father and son

\footnotetext{
${ }^{3}$ Regarding the figure and works of Stefano Pirandello, see Stefano Pirandello, Tutto il teatro, edited by Sarah Zappulla Muscarà and Enzo Zappulla, Milan, Bompiani, 2004, 3 volumes, pp. 1500.
} 
is confirmed by Valentino Bompiani, who was both friend and editor and who, on this subject, wrote, "Il rapporto di Stefano col il padre era del tutto fisiologico: Stefano aveva un cervello simile, ma critico, e Pirandello se ne serviva come di un proprio organo" (Pirandello \& Pirandello, 2008, p. 14). Stefano's relationship with his father became ever more intense as Luigi's existence became more frenetic and his writing activity spasmodic, punctuated as it was with long stays abroad. It was, as always, the son who, as he confesses to Corrado Alvaro on 22 August 1932, was to do everything in his power to allow his father to work with that "energia tranquilla e inesorabile che è il suopiù vivo desiderio". Stefano Landi always sought to foster his father's return to narrative, to those wide-ranging works that Luigi described as "conclusive": Informazioni sul mio involontario soggiorno sulla Terra and the novel Adamo e Eva, hovering somewhere between "mitico e umoristico". He was always to push him lovingly to achieve this enormous work, inviting him to come out of the "vicolo cieco" and abandon the dissipation of his theatre commitments and the even greater one of his cinema work. Why Landi? In a letter Luigi wrote to Ugo Ojetti on 10 October 1921, he states, "Si firma Stefano Landi per non mettere nella letteratura il guajo di un altro Pirandello. Ma ha un suo modo parti[co]lare di vedere e rappresentare la vita, che non ha niente da vedere col mio".

Why does Stefano choose to call himself Landi? The semantic excursus that the name invites is an illuminating one. Rather than from a suggestion of the homonymous 17th-century Roman musician and author of La morte di Orfeo, or of the neo-classical painter from Piacenza, Gaspare Landi, or, as Alberto Savinio suggests, the name of the Grand Duke of Tuscany's last executioner, Landi stems from Lando Laurentano, don Ippolito's son in I vecchi e i giovani, the intellectual socialist prince who waves the Risorgimento's flag, like the grandfather whose name he bears. It is therefore impossible for Stefano to escape the astonishing "giogo letterario che si chiama Pirandello" and, at the same time, feel creatively autonomous. The pseudonym is an eloquent screen deployed to assert a much sought-after autonomy that was won only late in the day and never fully attributed to him. "Stefano non vuole essere un ometto qualunque, un numero del gregge; Stefano vuole avere un valore suo, essere un'individualità", he wrote to his wife, Olinda, on 20 August 1921. Stefano owed much to his father's teaching and it could not be otherwise. However, as he wrote to Valentino Bompiani on 15 January 1945, he never used his father; rather, he was crushed by the weight of a dictatorship from which the moment had come to free himself. In this respect, in order to rescue Stefano from this jeu subtil regarding identity and let him feel himself to be a person fully alive in his own right, Luigi wrote to his sons, Stefano and Fausto Pirandello, in a letter from Turin dated 6 June 1926, "Non credere, mio caro Stefano, che non abbia cercato di farti entrare al 'Corriere della Sera”” (Pirandello \& Pirandello, 2008, p. 98). Indeed, a few days earlier, on 13 May 1926, Pirandello had written to Ugo Ojetti,

Ed ora ti vorrei rivolgere una affettuosa preghiera. Tu conosci mio figlio Stefano: so anzi che lo stimi giovane serio e d’ingegno, scrupoloso, fin troppo, nel suo lavoro; tale io lo stimo e tu sai che l'essergli padre non fa velo al mio giudizio. [...] Stefano si sente stranamente oppresso da una specie di giogo letterario che si chiama Pirandello ed è bene che qualcuno gli dica che anche lui è una persona viva. Se lo merita e da nessuno meglio che da te potrà venirgli la buona novella. (Pirandello, 1980, pp. 98-99)

The condition of son was always to weigh on Stefano. It can even be recognized in his choice of a pseudonym that connected his filial situation directly to that of Lando Laurentano, none other than the son of don Ippolito and in dispute with him. For Stefano, it was a form of dictatorship. One that Fausto escaped by choosing the artist's route and fleeing to Paris, where he became one of the most highly appreciated painters of the 20th-century due to his marked symbolic and metaphysical depth. A dictatorship that Lietta also fled, 
through a marriage that took her beyond her country's borders, to Chile. Racked by the traumatic and violent experience of deportation and imprisonment, and marked by a long series of sufferings and torments, Stefano, on the other hand, entrusted the function of testimony and denunciation to the literary word. A difficult goal to be striving for but one that Stefano achieved, sharpening his weapons against power's instrumental lies: that same power and those same lies that the sons in I vecchi e i giovani uncover and fight with lively minds and combative spirits. The battle is fought in order to overcome the scattered and uncontrollable conflicts that originate, primarily, from and within the family, that painful nest and bare trap in which, in the Freudian perspective, the germs of resentment are hatched and multiply, with all their misunderstandings, acts of connivance and interference: a metaphorical breeding ground for social conflict.

In I vecchi e i giovani, the author passes a very strict historical judgment on the unification process. Carlo Salinari (1960) talks of three collective failures, referring to the Risorgimento (as the impulse towards the country's general renewal), to unity (as the instrument for freeing and developing the most backward areas, particularly Sicily and Southern Italy), and to socialism (which could have been the resumption of the Risorgimento movement). These failures then overlap with the individual failures of the older generation that, because it was unable to develop the ideals in the light of concrete reality, was responsible for the young's corrupt conduct.

Applying this perspective to the Pirandello family nucleus, one can deduce how influential the figure of the father was on the son. The latter was always to feel oppressed by his father's intellectual supremacy, thereby demonstrating the profound awareness that, already at the beginning of the 20th century, was being achieved regarding the influence of the psychic relations between parents and children. Thus literature was offered the opportunity to become increasingly interested in human interiority, particularly within family relationships. Moreover, Freud himself had already intuited how the discoveries of psychoanalysis - the Oedipal complex, above all—would have profoundly influenced the artistic and literary cultural scene, enriching it in this way with new ideas since the concentration of the entire psychic life around the concept of order and subordination also conditions men's cultural output. There is no doubt that it was only after Freud that the issues revolving around the father-son relationship received wide-ranging coverage in literature. Vast and varied fields were embraced, ranging from novels to poetry. From this point of view, the biographical experiences of individual authors were highly important: Prompted by the new scientific theories, they felt the need to give vent to their own fears and feelings regarding that fathers always felt to be an insurmountable force; just as had occurred, in a chiastic perspective, with Stefano Landi/Lando Laurentano.

Luigi Pirandello, however, was aware of his son's intellectual subordination (as demonstrated above) and tried to rescue him from this bond, so as to let him feel himself a person fully alive in his own right: just as he was to do-passing to a constant play of mirroring-in I vecchi e i giovani when, on the subject of the young, he wrote:

La gioventù? Che poteva la gioventù, se l'avara paurosa prepotente gelosia dei vecchi la schiacciava così, col peso della più vile prudenza e di tante umiliazioni e vergogne? Se toccava a lei l'espiazione rabbiosa, nel silenzio, di tutti gli errori e le transazioni indegne, la macerazione d'ogni orgoglio e lo spettacolo di tante brutture? (2012, p. 350)

The old are those who have fought the wars of the Risorgimento and taken part in Garibaldi's enterprise; once the heroic climate is no more, many of them embrace a life of compromise, engulfed by their ambition for titles and power and incapable of solving the centuries-old problems posed by national life, while Rome 
becomes a city where everything can be sold and bought, the North pursues shady interests, and the South lives in destitution and ignorance.

The young are those who believe in the nation's social, civil, and political renewal. This is the generation that founds the Workers' Leagues and pushes whole provinces to revolt, convinced as it is that, "soltanto in Sicilia forse, or ora, la gioventù sacrificata potrebbe dare un crollo a questa oltracotante oppressione dei vecchi, e prendersi finalmente uno sfogo, e affermarsi vittoriosa!” Lando Laurentano, like Daniella Salvo and Aurelio Costa, belongs to the ranks of the young. An important exponent of the new generation, the possible new ruling class, he takes an active part in historical events, becoming a member of the Leagues' Central Committee. He, too, is a loser; however: a sort of ambitious, romantic superman, although not sharing in the movement's bloodthirsty degeneracies, he is forced into exile in order to escape capture.

Stefano Landi, on the other hand, after years living in the shadow of his father's monumental presence, was to succeed in liberating himself from the condition of intellectual exile only years after his father's death: only now do his plays appear no longer under the name of Stefano Landi but, rather, Stefano Pirandello (Pirandello, 2004).

\section{References}

Capuana, L. (1884). Spiritismo? Giannotta, Catania.

Corsinovi, G. (1979). Pirandello e l'espressionismo. Tilgher, Genoa.

Ellenberger, H. F. (1999). La scoperta dell'inconscio. Bollati Boringhieri, Turin.

Pirandello, L. (1972). Le opera. Mondadori, Milan.

Pirandello, L. (1980). Carteggi inediti (con Ojetti, Albertini, Orvieto, Novaro, De Gubernatis and De Filippo). S. Z. Muscarà, (Ed.). Bulzoni, Rome.

Pirandello, L. (1993). I vecchi e i giovani, with an introduction by Nino Borsellino and preface and notes by Massimo Onofri. Garzanti "I grandi libri”, Milan.

Pirandello, L. (2012). I vecchi e i giovani. S. Campailla, (Ed.). Newton Compton Editori, Rome.

Pirandello, L., \& Pirandello, S. (2008). Nel tempo della lontananza (1919-1936). S. Z. Muscarà and S. Sciascia, (Ed.). Caltanisetta-Rome, Bulzoni.

Pirandello, S. (2004). Tutto il teatro. S. Z. Mascarà and E. Zappulla, (Ed.). Bompiani, Milan.

Salinari, C. (1960). Miti e coscienza del decadentismo italiano. D’Annunzio, Pascoli, Fogazzaro, Pirandello. Feltrinelli, Milan.

Sciascia, L. (1996). Pirandello e la Sicilia. Adelphi, Milan.

Trombatore, G. (1962). Pirandello e i fasci siciliani. Riflessi letterari del Risorgimento in Sicilia: Studi sul secondo Ottocento. Manfredi, Palermo. 